\title{
AUGUSTINE AND PELAGIUS AS A CAMEO OF THE DILEMMA BETWEEN ORIGINAL SIN AND FREE WILL
}

\author{
Annette H.M. Evans \\ Research Fellow \\ University of the Free State
}

\begin{abstract}
According to St. Augustine's (354-430) literal reading of the myth of Adam's "fall", sin is transmitted to all humanity and leaves an uncontrollable inclination to sin. Salvation from this "original sin" can be achieved only by the grace of God, but the grace of God was mediated exclusively by the orthodox Roman church through the administration of the sacraments. One of the so-called "heretics" who was prepared to speak out against this authoritarian form of church "orthodoxy" was the Celtic monk Pelagius (360-c.420). He denied that sin is transmitted at birth. He claimed that sin was the result of an act of the will, choosing evil over good - and that divine grace cannot perfect humankind's sanctity without the exercise of one's own free will. Even though science and biblical textual criticism have prompted a new search for coherence between modernity and the life, death, and resurrection of Jesus Christ, some or other form of the doctrine of original sin is still being propounded in most Christian denominations today. In view of the tragic baggage that Christianity must bear, the question is raised regarding whether Pelagius's insistence on the choice to exercise free will for good through a Christ-like life would not have led to a more psychologically healthy and effective Christianity? This article employs a History-of-Religion's methodology to probe the politico-cultural historical context during St. Augustine's lifetime to understand how it came about that the doctrine of original sin was established. This article hypothesizes that the possibility (as claimed by Rowan Williams) of a "normative" Christianity containing "an interwoven plurality of perspectives on what was transacted in Jerusalem" is only achievable if the pre-Darwinian doctrine of inborn sin is relinquished in favour of Pelagius's insistence on accountability through an effort of will for good sustained by the grace of God.
\end{abstract}

Keywords: Original Sin; Free will; Augustine; Pelagius; Grace; Orthodoxy; Information technology; Cognitive dissonance; Science

\section{Introduction}

"Excessively trusted modes of knowledge, excessively relied-upon modes of power, have been shown to be inadequate. Our ways of theological interpretation must be changed. We are only at the beginning of thinking about how to proceed in fresh ways" (Brueggemann 2010:60, 81)

In a recent article concerned with the concept of original sin and accountability for the "land issue" in South Africa, Vorster (2020:6) states that a consequence of modernism 
is that the public domain demands rationality, not "outdated anthropology". With the exponential explosion of information technology, many Christians in the public sphere are experiencing cognitive dissonance. ${ }^{1}$ One of the culture-bound doctrines still being propounded in most Christian denominations today and still applied in child evangelism is the doctrine of original sin formulated by St. Augustine (354-430). The doctrine has been widely critiqued since the advent of modernism, but most Christian denominations still adhere to some form of the original sin doctrine, which is based almost entirely on a literal reading of the early chapters of Genesis. ${ }^{2}$ Do the scientific and psychological advances of nearly two millennia not change the validity of the doctrine of original sin? Van Huyssteen (2006:308-309) stresses the need for reconsideration of the "premodern notion of tradition as a repository of privileged data and specially protected, exclusive criteria". Ancient texts cannot be studied apart from their particular socio-political and religious contexts, and the world-views of those contexts cannot be derived solely from texts which later came to be regarded as canonical (Brooke 2013:227).

In the earliest orthodox forms of Christianity, the theme of "Fall-RedemptionJudgement" was central. Platonists, Origenists, Gnostics and Manichaeans all saw a primal fall in the spiritual realm as the explanation for human vulnerabilities, and so did St. Augustine (TeSelle 2006:77). The idea that all humans are sinful was present in the religious environment during Augustine's lifetime (Barr 1992:6-8). St. Augustine could not read Hebrew, so his interpretation was based on Latin and Greek translations. According to Augustine, Adam's "original sin" is transmitted to all humanity. The inherited corruption of the soul leaves an uncontrollable inclination to sin. Salvation, and thus eventually heaven, can only be achieved by the grace of God, but the grace of God was mediated exclusively by the orthodox Roman church through the administration of the sacraments. Outside of this corporate church, there was no salvation (TeSelle 2006:78). ${ }^{3}$ It was impossible to escape this tightly bound web-like paradigm unless one was prepared to risk persecution of some sort. ${ }^{4}$

The Fourth Industrial Revolution and digitization has brought about the blurring of the lines between the physical and the digital. A simple example is the GPS gadget, but robots and artificial intelligence are here to stay.

2 See Evans (2012:84). Consider Bottigheimer's (1995:21-22, 51, 202) observation that children's Bibles reflect changing social norms. For instance, in his approach to Primary School Biblical Studies, Lourens (1994:100103) states that humankind was originally created in a state of maturity and perfection, able to distinguish between right and wrong, and therefore born free to disobey God. By inculcating children with the dictum that disobedience is the essence of sin and that the punishment is death, the educational goal of obedience is achieved. Cf. The Doctrinal Standards of the Christian Reformed Church (1959)consisting of the Belgic Confession, the Heidelberg Catechism and the Canons of Dort: Article XV, Original Sin: "We believe that through the disobedience of Adam original sin is extended to all mankind; which is a corruption of the whole nature and a hereditary disease, herewith even infants in their mother's womb are infected, and which produces in man all sorts of sin, being in him as a root thereof, and therefore is so vile and abominable in the sight of God that it is sufficient to condemn all mankind."

3 In the Roman cultural context of the early centuries of Christianity, the concept of disobedience as the "original sin" committed by Adam and Eve conformed to the Roman cultural context, not only as a simple answer to theodicy but also because punishment for disobedience suppressed any inclination to usurp the power-basis of the Roman empire. Te Selle (2006:78) observes that the "imperial measures against paganism" had financial and political benefits for the state- run Roman church.

4 See Spangenberg (2014:620) for his diagram of five interlocked and interconnected pentagons which demonstrate the tightly-knit system that makes it practically impossible to escape from the dogma of original $\sin$. 
One of the so-called "heretical" voices who was prepared to speak out against the authoritarian form of church "orthodoxy" was the Celtic monk Pelagius (360-c.420). Pelagius, an almost exact contemporary of Augustine, was a learned "man of culture", fluent in Latin and Greek, and is reputed to have known the Scriptures extremely well. He had no institutional authority, but even St Augustine credited "the heresiarch" with an "active, subtle, and penetrating intellect, an ardent soul, and even a certain reputation for holiness" (Gougaud (1992, 24), quoting from De Peccat. Mer., III, 1, 5).

\section{Methodology}

Just as the Gutenberg printing revolution facilitated the Reformation, so now the scientific and technological penetration into all spheres of life necessitates a review of the tenets and practice of Christianity. The disciplines of science and biblical textual criticism have prompted a new search for coherence between our current cultural context and the way we understand the life, death, and resurrection of Jesus Christ. New methods of reading venerated canonical texts are being applied to give relevant and coherent meaning to present experience. ${ }^{5}$ This article looks backwards by means of a History-ofReligion's methodology to understand how the doctrine of original sin was arrived at and why it is still adhered to today in most Christian denominations. Loumagne (2017:189) recognizes the risk of being perceived by Christian fundamentalists as antagonistic to established Church norms when thinking creatively in this regard. Padilla (2018:67-79) has acknowledged the orthodox fear that "to accept the challenge of theological liberalism would be, plain and simple, to abandon Christianity". In view of modern insight into ancient ideological rhetoric, this article probes briefly and broadly into the politico-cultural historical context during St. Augustine's lifetime in order to try to understand why any form of the doctrine of original sin is still held to be tenable. ${ }^{6}$

\section{Augustine and Original Sin}

St. Augustine based his doctrine of original sin on the Yahwist narrative of the disobedience of Adam and Eve described in Gen 2:4b to 3:24. He found confirmation for his formulation in his reading of Paul's rhetorical statements in Romans 5:19-20, where Paul compares Jesus to Adam. The source of Paul's statements has been traced to the earliest expression of the idea of inherited communal sin in the apocryphal fourth (second) book of Esdras 7.118: "O Adam, what have you done? For though it was you who sinned, the fall was not yours alone, but ours also who are your descendants". 7 This text dates to the destruction of the second Temple in $70 \mathrm{CE}$ and should be understood in its context of Deuteronomic theology and theodicy, which had a characteristically communal and retributive "cause and effect" view of God's justice (Kiel 2011:281). The entire community shared in individual sin: faithfulness to Yahweh's covenant brought

See for instance Moore's barbed critique of the kind of exegesis "that will not disturb the tranquil dreams of the traditionally minded biblical scholar" in Kelley's review of Fiona C. Black and Jennifer L. Knoosed. (eds.), 2019. Reading with feeling: Affect theory and the Bible (Shawn Kelley, Review of Biblical Literature [http://www.bookreviews.org] (2020).

6 See Amit, Y. 2000. Hidden Polemics in Biblical Narrative, transl. from the Hebrew by J. Chipman, Brill, Leiden.

7 Westermann (1974:108). Esdras 2 (Four) is extant in Codex Sangarmanensis 1 7:106-7:140, restored in the Stuttgart edition of the Vulgate: Biblia Sacra Vulgata 1994, ISBN 3-438-05303-9. 
success, disobedience brought failure (Laato 2003:183-235). According to Deuteronomistic theology, worship was centralised and focused on the Jerusalem Temple, so after the destruction of the Temple in 70CE, original sin was considered an obvious, if facile, explanation regarding the origin of evil in the world.

Barr (1992:7) points out that mainstream Jewish tradition has refused to accept any sort of doctrine of original sin: "Within the Hebrew Bible itself the story of Adam and Eve is nowhere cited as the explanation for sin and evil in the world". The word "sin", חטאת, does not appear at all in the passage (Gen 2:4b to 3:24) upon which St Augustine based his doctrine of original sin. The first mention of the word "sin" in the Hebrew Bible appears much further on in the narrative: Gen 4:7 indicates that Cain should have exercised willpower to avoid sin. In Gen 4:7 Cain does not do "well" and chooses to "sin" by murdering his brother: "If you do well, will you not be accepted? And if you do not do well, sin is crouching at the door; its desire is for you, but you must master it" (RSV). Logically, if humankind were to have the responsibility and ability to choose to master sin, humankind had to have knowledge of good and evil to "do well". According to Jewish tradition, God provides humans with the impulse to do evil and to do good, so that sin stems from human beings making the wrong choices. The Hebrew Bible assumes the possibility of avoiding sin, but those who sincerely repent for the wrongs for which they are responsible can gain forgiveness.

St. Augustine's understanding of Genesis 2-3 was complicated by the fact that, as is clear in his Confessions, he personally had a great struggle with concupiscence. For Augustine, the human struggle was a microcosm of the cosmic conflict. In his youth, the dualism of Manichaeanism had appealed to him because evil was regarded as a tangible force which originated in a separate realm to that of good; the Manichaens saw the "glow of sexual delight" as a trick by which good is kept in captivity (TeSelle 2006:21). Psychological criticism in the case of Augustine's doctrine of original sin heightens our awareness of a text as expression of a psychic as well as historic process. ${ }^{8}$ The modern discipline of psychology offers a deeper and broader understanding of how potentially "toxic" doctrines, totally unrelated to the teachings of Jesus Christ, could have arisen (Davis III 2007:232-235). In terms of a psycho-critical hermeneutic, it is likely that Augustine projected his own problem into his reading of the story of Adam and Eve and its subsequent development into the doctrine of original $\sin .{ }^{9}$ St. Augustine saw an inevitable connection between the sexual nature of human procreation and childbirth and universal human corruption. Consequently, he claimed that every human being is corrupted from birth and can only be saved from that corruption by the grace of God made available through the crucifixion and resurrection of Jesus Christ. ${ }^{10}$ The profound influence of St. Augustine's hermeneutic can be seen for instance in the crucial controversy concerning infant baptism. To this day, the doctrinal standards of the Christian Reformed church require the parents to acknowledge that "our children, though conceived and born in sin and therefore subject to all manner of misery, yea, to

8 Stein (2007:24-32) explains how psychology helps to "see the religious belief system and its tradition in increasingly realistic terms, affirming their inherent tensions and ambiguities, and accepting the relativity, partiality, and particularity of the beliefs, symbols, rituals, and ceremonials of the religious community." Brueggemann (2010:65) commented that there is no interest-free interpretation.

10 See Spangenberg (2014:6613): In the hermeneutical debate around Adam and Eve's "Fall", the doctrine of original sin is a human construct - "a classic example of eisegesis". 
condemnation itself, are sanctified in Christ, and therefore as members of his Church, ought to be baptized".

\section{Pelagius's alternative to the doctrine of original sin}

When Pelagius arrived in Rome from the British Isles in about 385, he was shocked to see that bishops and priests had rapidly begun to acquire great wealth and power. ${ }^{11} \mathrm{He}$ expressed his indignation at the low state of morals in no uncertain terms:

"Do you consider him a Christian in whom there is no Christian act, in whom there is no righteous conduct, but evil, ungodliness and crime? Do you consider him a Christian who oppresses the wretched, who burdens the poor, who covets others' property, who makes several poor so that he may make himself rich, who rejoices in unjust gains, who feeds on others' tears, who enriches himself by the death of the wretched, whose mouth is constantly being defiled by lies, whose lips speak nothing but unworthy, foul, wicked and base words, who, when ordered to distribute his own possessions, seizes others' instead? And a man of this kind has the audacity to go to church and thoughtlessly and inappropriately stretches out his impious hands ..." 12

Pelagius came to see a connection between the immoral state of the clergy and the view on divine grace repeated several times in Confessions, where St. Augustine addresses God as follows: "If you give what you command, then command what you wish". Pelagius interpreted this statement as putting all initiative in the hands of God, thus denying altogether the possibility of any free exercise of one's own will, i.e., personal responsibility. Pelagius expressed his objection by writing On Nature, in which he claimed that divine grace cannot perfect our sanctity without the exercise of our own free will. Pelagius maintained that a child is born innocent and free from sin, emphatically denying that sin is transmitted at birth (or conception). To Pelagius, all children are born manifesting the glory of God - sin was the result of an act of the will, choosing evil over good. More than a millennium after Augustine's death, Pelagius's view still had to be defended against, as can be seen in the closing sentence in Article XV on original sin in the Belgic Confession of Faith (1561): "We believe that through the disobedience of Adam original sin is extended to all mankind; which is a corruption of the whole nature and a hereditary disease, wherewith even infants in their mother's womb are infected, and which produces in man all sorts of sin, being in him as a root thereof, and therefore is so vile and abominable in the sight of God that it is sufficient to condemn all mankind ... Wherefore we reject the error of the Pelagians, who assert that sin proceeds only from imitation."13

Rees (1988:119) quoting Van der Weyer 1955.

12 On the Christian life (397 CE or 400 CE: X, xxix, 40 - xxxvii, 62), attributed to Pelagius by R. F. Evans (1968: 15ff, 120ff). In the next decade Pelagius wrote For Free Choice. Unfortunately, both are now lost. Modern research into Pelagianism only began at the beginning of the twentieth century. See Rees (1988:7) for a nuanced summary of Pelagius's views.

13 The formula of the Dutch Reformed Church baptism is still framed in terms of a view that for humans, to be fruitful and multiply by means of sexual reproduction is sinful. The Heidelberg Catechism (1563) Lord's Day III, question 7, asks: "Whence, then, comes this depraved nature of man? ... From the fall and disobedience of 
In expounding his position on free will and the possibility of sinlessness, Pelagius fell foul of Bishop Jerome and attracted the attention of St. Augustine. Pelagius provoked Augustine's ire with his claim that it is possible to achieve inpeccantia (sinlessness) if one applied one's will to live an ethical and ascetic life. Augustine interpreted Pelagius's statements as putting free will in the place of grace as the means of salvation and responded by writing that the will to good itself is inert unless it is quickened by the Holy Spirit (Edwards 2011:610). Pelagius, on the other hand, in his commentary on the Epistle to the Romans, states that "faith enables those who law condemns, and it is by faith that we escape the constraints of fallen nature, working perfection after the example of the saints" (Edwards 2011:613, quoting Pelagius' Commentary on the Epistle to the Romans, chapter three, page 88).

In his Letter to Demetrias, Pelagius stresses the importance of the part played by the human will in enabling individuals to choose and perform right actions and so to win salvation, and he claims that human beings have "a kind of natural sanctity". ${ }^{14}$ To him, the church community was merely the mediator of salvation by means of guidance, teaching and support. The following excerpt from a letter Pelagius wrote to his follower Rufinus reflects the difference, not only in opinion, but also in attitude and personality between Pelagius and Augustine:

Surely, we are not nursed with sin, but are created free to choose good or evil. How much greater to choose - and to freely choose good - than to be like the bees and the fishes. Every morning we can awake and seize the day with our will, not wrapped in animal flesh, in the tyranny of our instincts, but awesomely free. Free to do great things, Rufinus (Bury 1905:19, quoting De Natura).

When in 410 Rome was sacked, Pelagius took refuge in Carthage, Tunisia. By the time he arrived in Carthage, he was supported in Southern Italy, Sicily, Alexandria, by the Jerusalem Christians, by Origenists throughout the East, and by the patriarch of Constantinople. Evidence that Pelagius's view was well known and appreciated came to light in 1883 when an image of Pelagius depicted on the coffin of a child was found at Tabarka, Tunisia. ${ }^{15}$

To Augustine and Jerome, Pelagius's view that humankind needed no extraordinary gift of grace administered by the Church to accomplish salvation struck at the Roman Church and at their own notion of redemption. Augustine "asserted that the Holy Spirit dwells only within the Catholic Church and salvation is impossible outside it" (TeSelle 2006:42). Pelagius was seen to be undermining the global spread of their authoritarian Christianity, and the Roman church realised that the spread of the "heresy" of Pelagius was preventing the creation of a global church. Augustine had the political skills to build strong campaigns against his opponent. Consequently, he worked towards the eradication of the "arch-heresy" of Pelagianism. Augustine was a prolific writer and

our first parents, Adam, and Eve, in Paradise, whereby our nature became so corrupt that we all are conceived and born in sin" (Doctrinal Standards of the Christian Reformed Church, 1959:8-9, 23).

14 Pelagius (4, 25ff. PL.22 30, 19; 33, 1101), quoted by Bonner (2017: 341-352).

15 Now in the Louvre, Paris, Department of Greek Etruscan and Roman antiquities, Ma 2995, MNC 605. Until recently, the Roman Catholic church refused burial within a churchyard if the soul was not "saved" by baptism before death. 
wrote De Spritu et Lettera against Pelagius and his supporters in Carthage (Gougaud 1992:40). After repeated hearings, Pope Zosimus eventually succumbed to pressure and excommunicated Pelagius in 418. ${ }^{16}$ The meagre remains of Pelagius's interpretation of the teaching of Jesus are now extant mainly in fragments or can only be read between the lines of the writings of his critics. ${ }^{17}$ Although Augustine "refashioned Pelagius as his antitype", and Pelagius rejected any theory of a hereditary defect or a heredity sin transmitted from Adam to his posterity, much common ground remained (Edwards 2011). The essence of the division between Augustine and Pelagius was the relation between grace and sin. Whereas Augustine insisted that grace is necessary to make the fallen will free, and that without the preliminary exercise of God's goodness administered by the church, humankind would never be free from sin, Pelagius was basically resisting "the pressure of ecclesiastic-political developments" (Williams 1989:17).

\section{Discussion}

The trigger that set off modern research into Pelagius may have been an influential article by Tennant in 1905 which stressed the volitional and intentional character of $\sin .{ }^{18}$ As seen logically in the public sphere, if original sin points to a common sinfulness of mankind that lies beneath isolated sinful deeds, sin is statistically inescapable and yet still entails responsibility; responsibility entails freedom of choice. Thus, an anomaly arises: if "fallen" man is to have freedom of choice, the starting point that man is innately sinful undermines the freedom of the human will. Augustine responded to this anomaly by claiming that salvation is not dependent on any prior human response to God's call but purely on God's "election". The implication is that even after the soul has been cleansed in baptism by the church, not all souls are predestined to be saved (TeSelle 2006:77, 81). Te Selle relates this claim to Augustine's reading of St. Paul's writings and suggests that Augustine had of necessity to affirm predestination to counter Pelagius' insistence on free will. If God's grace overrules the human will, the only solution would indeed be predestination as Augustine claimed. In his commentary on Romans (now no longer attributed to Jerome but to Pelagius), Pelagius denied that Paul endorsed any form of predestination. ${ }^{19}$ In his claim that faith and effort of will alone are necessary if people are to succeed in their struggles against sin and that the possibility to be sinless is never damaged or diminished, Pelagius did not deny that they received grace from God (Bury 1905:28).

Ricoeur (1913-2005) recognized that Pelagianism has drastic implications for orthodox Christology and the Pauline doctrine of grace. Ricoeur regarded Augustine as mistaken (because of a literal reading) in viewing Adam as the first agent of sin, whereas

16 Gougaud (1992:22). In 429, the church of Gaul sent Germanus, bishop of Auxerre, to bring back the British Pelagians to orthodox belief (Molloy 2009:98; Gougaud 1992:25). Many of the Irish monastic territories became episcopal sees. Subsequently, the Celtic monk Columbanus b. 543 left Ireland with a band of 12 monks and founded monasteries throughout France, Germany, Switzerland, and Italy, but under Pope Gregory I (604-606) Benedictine monasticism became the key element of a strategy to eliminate Celtic monasticism from mainland Europe.

17 See Rees (1988:134) for a complete list of Pelagius's extant writings. There are also 1311 marginal comments and interlinear glosses originating with Pelagius in the Epistles of Warburg and the copy made by Marianus.

18 Tennant (1912:93). See Chappell (2013:154) on Tennant's influential work.

19 See Edwards (2011:609) for the complexity of problems related to predestination. 
from a mythic point of view he was only the first vehicle of $\sin .{ }^{20}$ Vorster does not relinquish the idea of a universal sinfulness. He does, however, note that Barth suggested that the idea of inherited sin should be abandoned and that Niebuhr claimed that original sin contradicts the idea of human responsibility for sin, but he acknowledges the "danger of collectivist and arbitrary notions of guilt or innocence", and "the risk of loss of the link between accountability and human agency", but he also recognises the danger of reducing Christ to a moral teacher and grace to external divine guidance. Consequently, he insists that "We are, in Paul's words, slaves of sin." In the same vein, Loumagne (2017:189) asks, "while the doctrine of original sin is particularly offensive to postEnlightenment sensibilities, how can we speak of the salvation offered in Jesus Christ if we cannot speak of sin?" This is a relevant question. ${ }^{21}$ In relation to the apparently insoluble question of sin and its relation to the origin of evil, I would like to suggest that it will remain insoluble until the concept of universal sinfulness is relinquished, at least temporarily for the sake of exploration. Pelagius claimed that although by baptism adults were cleansed of the sins they have committed, apart from teaching and support after baptism, they needed to exercise their own willpower to remain righteous (Rees 1988:77). Perhaps the real issue between St. Augustine and St. Pelagius was not either grace or free will, but the manner in which God's grace is bestowed. To Pelagius, it was

20 Vorster (2020:7): in terms of the natural history of mankind, Ricoeur understood Augustine to claim "a quasibiological transmission of a quasi-juridical guilt for the fault of another man, back into the night of time somewhere between Pithecanthropos and Neanderthal man." Furthermore, Ricoeur understood Augustine to have based his doctrine of original sin on an erroneous exposition of Romans 6:16-17.

21 Consider the current variations on the doctrine (www.bbc.co.uk>religion>beliefs. Religion - Christianity: Original Sin - BBC. Accessed 8 Oct 2020.

1. Bishop John Shelby Spong, A Call for a New Reformation, 1988: "The biblical story of the perfect and finished creation from which human beings fell into sin is pre-Darwinian mythology and post-Darwinian nonsense".

2. Original sin has been criticised for inspiring excessive feelings of guilt. The $18^{\text {th }}$-century politician and philosopher Edmund Burke once said, "Guilt was never a rational thing; it distorts all the faculties of the human mind, it perverts them, it leaves a man no longer in the free use of his reason, it puts him into confusion." Is the feeling of guilt a vital part of our moral lives or can it do more harm than good?

3. Protestant - modern: Many modern Protestants would not take quite such a gloomy view of humanity as Calvin and would not regard humankind as evil in essence without any trace of the divine image. They would still teach that human beings are 'fallen' and need to 'get right with God', by believing that Christ's death 'atoned' for their sin, accepting that they can only be 'saved' by God's freely given 'grace' and being baptised.

4. Orthodox teaching: The Christian Orthodox churches do not interpret original sin in the way that Augustine did. They do not accept that people can be guilty of a sin they did not commit, and so they reject the idea of inherited guilt passed down the generations. The Orthodox interpretation of original sin is that the way in which human beings inherit sinfulness is that human history, culture, and society have created a moral climate which disposes human beings to behave sinfully; as a result, all people need God's help to avoid sin.

5. Roman Catholic teaching: The teaching of the Roman Catholic Church was summarised by Pope Paul VI (1968): We believe that in Adam all have sinned, which means that the original offence committed by him caused human nature, common to all men, to fall to a state in which it bears the consequences of that offence, and which is not the state in which it was at first in our first parents, established as they were in holiness and justice, and in which man knew neither evil nor death. It is human nature so fallen, stripped of the grace that clothed it, injured in its own natural powers, and subjected to the dominion of death, that is transmitted to all men, and it is in this sense that every man is born in sin. We therefore hold, with the Council of Trent, that original sin is transmitted with human nature 'not by imitation, but by propagation' and that it is thus 'proper to everyone.' We believe that our Lord Jesus Christ, by the sacrifice of the cross, redeemed us from original sin and all the personal sins committed by each one of us, so that, in accordance with the word of the Apostle, 'Where sin abounded, grace did more abound'." 
not that God's grace was not a reality, but he insisted that adult baptism for instance is simply a sacrament of faith - salvation lay in the way one lived one's life, and it was available to all.

It was St. Augustine who first coined the word "inerrant" in relation to Scripture (Horton 2011). Yet even Calvin, who emphasised the supreme authority of Scripture, recognised that acceptance of the inerrancy of the Bible does not close down the question of how it is to be interpreted (Horton 2011). The following statement ascribed to Pelagius (Letter to a New Christian, $380 \mathrm{CE}$ ) demonstrates his clarity of mind and how far ahead of his times he was:

"You will realize that doctrines are the invention of the human mind, as it tries to penetrate the mystery of God. You will realise that scripture itself is the work of human minds, recording the example and teaching of Jesus. Thus, it is not what you believe (in your head) that matters, it is how you respond with your heart and your actions. It is not believing in Christ that matters but becoming like Him." 22

At the very least, the Pelagian controversy served a purpose in that it brought out hidden tensions and conflicts within the Christian tradition (Lohr 2007:31). The issue of original sin is increasingly being reconsidered from an interdisciplinary orientation. Modernity has brought the recognition that even religion is primarily concerned with providing explanatory theories, and even children are sensitive to the underlying causal structure of the world and seek to form new explanatory representations at a much earlier age than had previously supposed (Gopnik 2000:203-204). Loumagne (2016:189) points out that "sin language" easily devolves into dualistic thinking and resultant attacks on "the enemy". Radical dualism is an unhealthy and adolescent response to the nuances and ambiguities of modern life (DiTommaso 2011:234, 236). It has been claimed that Augustine's doctrine of original sin "left people feeling corrupted, ashamed and powerless ... They learnt to feel permanently guilty. They were perpetual sinners" ${ }^{23}$ To be relevant to its audience, biblical interpretation must yield adequate contextual effect. ${ }^{24}$ For instance, from a psychological orientation, the eating of the fruit by Adam and Eve is a symbolic act of becoming conscious - it represents "the beginning of humanity's painful step into moral and psychological awareness and away from unconscious containment in purely natural existence" (Sanford 2007:163, 165). The garden of Eden narrative continues by describing how, while not minimising the consequence of sin, God shows his care for sinners in placing a protective mark on Cain. The result is positive: self-consciousness (i.e., knowledge of good and evil) in the context of the experience of God's care. The final state is the recognition of the responsibility to choose to do well. Temptation has something positive to offer having fallen for it, mankind gains insight into the power of sin. Hence in Jungian terms, for example, the real meaning of the Garden of Eden story is that the development of the narrative is the trigger for the moral and spiritual growth that is the prerequisite for individuation.

22 Quoted by Molloy (2009 195) and by New World Encyclopaedia, but no further reference is given.

23 Molloy (2009:201-203). For instance, see the "Hail Holy Queen", a traditional prayer recited at the end of the Rosary. "Poor banished children of Eve ... sinful and sorrowful ... mourning and weeping in this valley of tears."

24 Evans (2013; 2014:1). 


\section{Conclusion}

In view of the tragic baggage that Christianity carries, and with current psychological insight it is not unreasonable to ask whether Pelagius's concern with mankind's lack of accountability in response to God's grace might not have led to a more psychologically healthy and effective alternative for a Christ-like life. Yet, he was "one of the most maligned figures in the history of Christianity" (Rees 1988: xi).

Pelagius understood the most fundamental meaning of grace to be as follows: God's gift to humankind is good nature which consists "primarily of the feeling, choosing, and doing the good" (VanderVelde 1975:47, quoting from Pelagius De Natura). Consciousness of God's grace is not yet coherent with explanations of current scientific knowledge about the origin of the world as we know it today (see Evans 2014:1), but as Van Huyssteen (2006:308) points out, the rigid modernist disciplinary distinctions need to be collapsed.

Williams (1989:17-18) acknowledges that there are "insuperable problems in supposing there to have been from the beginning a single, clearly identifiable 'mainstream', as for instance in the post-Nicene development of 'imperial orthodoxy". Yet, Williams asserts that there are features within the most basic activity of communicating about Jesus that $d o$ "make for the precarious evolution of a 'normative' Christianity which is still an interwoven plurality of perspectives on what was transacted in Jerusalem". Williams points out that the development of canon and orthodoxy "preserved the possibility of preaching Jesus as a questioning and converting presence in ever more diverse cultures and periods, and the possibility of intelligible debate and self-criticism within Christianity". Our task is no different now than in Augustine and Pelagius's time: to keep questioning and searching for the essence of the meaning of the life, death, and resurrection of Jesus Christ for our own cultural context. In the search for meaning in our exponentially changing world, Christians must accept the challenge of troublesome reorientations of understanding of the timelessness of the gospel of Jesus Christ. In the face of the fourth industrial revolution, we need Christianity more than ever to remind us to put our human capacity for emotion, compassion and creative problem solving into practice in the real world. ${ }^{25}$

\section{BIBLIOGRAPHY}

Amit, Y. 2000. Hidden polemics in biblical narrative, transl. from the Hebrew by J. Chipman, Leiden: Brill.

Barr, J. 1992. The Garden of Eden and the hope of immortality. Minneapolis: Fortress Press.

Bonner, A. 2017. The Manuscript Transmission of Pelagius's Works and the Implications, with Special Reference to his Letter to Demetrius, Studio Patristica 74:341-352.

Bottigheimer, R.B. 1996. The Bible for children: From the age of Gutenberg to the present. New Haven/ London: York University Press.

25 This article is the culmination of research started by David Evans. Many intense discussions with him until his death in 2013 are thankfully acknowledged with profound respect. 
Brooke, G.J. 2013. Reading the Dead Sea Scrolls: Essays in method. Early Judaism and its literature 39. Atlanta: Society of Biblical Literature.

Brueggemann, W. 2010. Genesis. Interpretation: A Bible commentary for teaching and preaching. Atlanta: John Knox, [1982].

Bury, J.B. 1905. The Origin of Pelagius, Hermantheia 13 (30/31):26-35.

Chappell, J.W. 2013. Rethinking the Historical Fall in the light of evolution: F. R.

Tennant and after, Science and Christian Belief 25:131-154.

Davis III, C.T. 2007. Defining a Toxic Text. in Rollins, W.G., and Kille, D.A. (eds.), Psychological insight into the Bible. Texts and readings. Grand Rapids,

MI./Cambridge, U.K.: Wm B Eerdmans Publishing Company, 232-235.

DiTommaso, Lorenzo. 2011. The apocalyptic other. in Harlow, Daniel C. (ed.) The "Other" in Second Temple Judaism. In Honour of John J. Collins. Grand Rapids, Mich.: W.B. Eerdmans, 221-246.

Edwards, M. 2011. Augustine and Pelagius on the Epistle to the Romans. in Lieb, Michael, Mason, Emma, Roberts, Jonathan, and Rowland, Christopher (eds.), The Oxford handbook of the reception history of the Bible. Oxford: UP, 609-619.

Evans, A.H.M. 2012. Evangelism of young children: Is an evolutionary understanding of 'Original Sin' possible?, OTE 25/1:84-99.

Evans, A.H.M. 2013. The Bible for children in a postmodern context: How does children form explanatory concepts?, Verbum et Ecclesia 35(1), Art. \#820, 7 pages. http://dx.doi.org/10.4102/ve.v35i1.820.

Evans, A.H.M. 2014. "The Bible for children in a postmodern context: How do children form explanatory concepts?"Verbum et Ecclesia 35(1), Art. \#820. 7 pages. http://dx.doi.org/10.4102/ve.v35i1.820

Evans, F.R. 1968. Pelagius: Inquiries and reappraisals. London: Routledge.

Evans, F.R. 1968. Four letters of Pelagius. London: Routledge.

Gopnik, A. 2000. Explanation as orgasm and the drive for causal knowledge: The function, evolution, and phenomenology of the theory formation system. in Keil, Frank, and Wilson, Robert (eds.), Explanation and cognition. Cambridge, Mass./London: the MIT Press, 299-323.

Gougaud, L. 1992. Christianity in Celtic lands. A history of the churches of the Celts, their origin, their development, influence and mutual relations, Transl. by Maud Joynt. London/Dublin: Four Courts Press, [1932].

Horton, M. 2011. The truthfulness of Scripture: Inerrancy, https://biologos.org. Accessed 22 Aug 2020.

Kiel, M.D. 2011. Tobit's theological blindness, CBQ 73: 281-298.

Kelley, S. 2020. Review of Fiona C. Black and Jennifer L Knoosed (eds.), 2019.

Reading with Feeling: Affect Theory and the Bible.Review of Biblical Literature, [http://www.bookreviews.org] (2020)).

Laato, A. 2003. Theodicy in the Deuteronomistic History. in Laato, Anti and de Moor, Johannes C. (eds.), Theodicy in the world of the Bible. Leiden: Brill.

Lohr, W. 2007. Pelagius - portrait of a Christian teacher in Late Antiquity. Alexander Souter Memorial Lectures on late Anticuity - 1 (Inaugural) 2006. Aberdeen: University of Aberdeen.

Loumagne, M. 2017. The rise of fundamentalism and the concept of sin, An Irish Quarterly Review. Studies, 106(42): 183-192. 
Lourens, M. J. 1994. "Sin”, in Biblical Studies. A Primary School View, 100-103. Lourens, "Sin", in Biblical Studies. A Primary School View, (1994):100-103 (100-101).

Molloy, D. 2009. The globalization of God. Celtic Christianity's nemesis. Aran Islands: Aisling Publications.

Padilla, O. 2018. The Future of Inerrancy: Do Postliberals point the way forward?, Presbyterian 44 (1) (Spring 2018): 67-79.

Rees, B.R. 1988. Pelagius: A reluctant heretic. Woodbury, Suffolk/Rochester N.Y.: The Boydell Press.

Sanford, J.A. 2007. The story of Adam and Eve. in Rollins, W.G. and Kille, D.A. (eds.), Psychological insight into the Bible. Texts and readings. IGrand Rapids, MI./Cambridge, U.K.: Wm B Eerdmans Publishing Company, 160-165.

Spangenberg, I.J.J. 2014. Kollig op Genesis 1-3: 'n Verslag van verskuiwende denke en geloof, OTE 27 2: 612-630.

Stein, D. 1980. Is a psycho-analytic reading of the Bible possible? in Kung, Hans and Moltmann, J. (eds.), Conflicting ways of interpreting the Bible. New York, Seabury/Edinburgh: T\&TClark

Tennant, F.R. 1912. The concept of sin. Cambridge: Cambridge University Press.

Te Selle, E. 2006. Augustine. Abingdon pillars of theology. Nashville: Abingdon Press.

VanderVelde, G. 1975. Original Sin: Two major trends in contemporary Roman Catholic Reinterpretation. Amsterdam: Rodopi N/V.

Van der Weyer, R. (ed.). 1955. The letters of Pelagius. Celtic soul friend. Evesham: Arthur James Ltd.

Van Huyssteen, W.J. 2006. Alone in the world? Human uniqueness in science and theology. The Gifford Lectures, University of Edinburgh, Spring 2004. Grand Rapids, Mich.: Wm B. Eerdmans Publishing Company Ltd.

Vorster, N. i2020. "Land disposition as 'Original Sin'. Can Christian Original Sin Talk be used as Diagnostic Tool within the Public Domain?" Scriptura 119 (2020:2): 120.

Westermann, C. 1994. Creation. Translated by John J. Scullion, S.J. London: SPCK. [1974].

Williams, R. 1989. Does it make sense to speak of pre-Nicene orthodoxy?. in Williams, Rowan (ed.), The making of Orthodoxy. Essays in honour of Henry Chadwick. Cambridge University Press: Cambridge/New York/Rochester/New Swansea/Sydney. 